DOI https://doi.org/10.30525/978-9934-26-182-4-6

\title{
ЕНДОТЕЛІАЛЬНА ДИСФУНКЦІЯ ПРИ КОРОНАВІРУСНІЙ ХВОРОБІ COVID-19
}

\author{
Габшидзе Н. О. \\ аспірант кафедри внутрішньої медицини 1 \\ Дніпровський державний медичний університет \\ Фуголь К. В. \\ аспірант кафедри внутрішньої медищини 1 \\ Дніпровський державний медичний університет \\ Щудро О. О. \\ аспірант кафедри внутрішньої медицини 1 \\ Дніпровський державний медичний університет \\ м. Дніпро, Україна
}

Коронавірусна хвороба COVID-19 - це гостра респіраторна інфекція, викликана вірусом SARS-CoV-2. Одним 3 ключових компонентів патогенезу COVID-19 є розвиток або посилення вже наявної ендотеліальної дисфункції [2, с. 41]. Bipyc SARS-CoV-2 інфікує клітини шляхом взаємодії з рецепторами ангіотензин-перетворюючого ферменту 2 (АПФ-2), внаслідок чого у крові підвищується рівень ангіотензину II, олігопептіду 3 вазоконстрикторними та антифібринолітичними властивостями [3, с. 2]. Рецептори АПФ-2 розташовані не тільки в альвеолах, але й в ендотеліоцитах, що зумовлює пряме пошкодження ендотелію вірусом [9, с. 3]. Індуковане COVID-19 системне запалення і цитокіновий шторм у свою чергу провокують запалення ендотеліоцитів опосередковано, що разом 3 прямою цитотоксичною дією вірусу призводить до активації системи комплементу і тромбоцитів, розвитку ендотеліопатії та прокоагулянтного стану $[5$, с. $6 ; 11$, с. 6]. Підвищення в крові рівнів таких маркерів ендотеліальної дисфункції, як фактор фон Віллебранда, тканинний активатор плазміногену, інгібітор активатора плазміногену 1 типу, розчинний тромбомодулін прямо корелює 3 негативним прогнозом у хворих на COVID-19 [7, с. 4].

Більшість людей, які хворіють на COVID-19, одужують повністю протягом кількох тижнів, але у деяких пацієнтів має місце тривале збереження симптомів захворювання [4, с. 53]. У 10-50\% осіб, які перехворіли на COVID-19, через 6 місяців не відновлється повністю 
рівень здоров'я та функціональні можливості [1, с. 16]. Зумовлені SARS-CoV-2 системне запалення та ушкодження ендотелію, ймовірно, характеризуються синергізмом $[11$, с. 8]. Деякі дослідження підтверджують гіпотезу про персистенцію ендотеліальної дисфункції в постковідному періоді. У осіб, які перенесли COVID-19, зниження ендотелій-залежної вазодилатації, визначеної за допомогою ультразвукового дослідження, корелює 3 вираженістю клінічної симптоматики та порушень функції зовнішнього дихання [6, с. 6]. У реконвалесцентів по COVID-19 виявляються значно підвищеними рівні розчинного тромбомодуліну та антигена фактора Віллебранда, при чому останній показник негативно корелює 3 результатами тесту 3 6-хвилинною ходьбою [8, с. 2551]. Також для періоду реконвалесценції характерне підвищення рівня ендотеліну-1 - біомаркера, який характеризує ендотеліальну дисфункцію та відображає процеси неоангіогенезу i розвитку легеневої гіпертензії $[12$, с. 3]. При негоспітальних пневмоніях іншої етіології також спостерігається підвищення рівня ендотеліну-1, але тільки у тяжких хворих, на відміну від коронавірусної хвороби, коли підвищення рівня ендотеліну-1 характерно і для нетяжкого перебігу вірус-асоційованої пневмонії [10, с. 1464, 2019; 12, с.1].

Таким чином, необхідно проводити дослідження, аби у подальшому визначити особливості ендотеліальної дисфункції у осіб, які перенесли COVID-19, а також встановити іiі вплив на вираженість клінічної симптоматики та ризик розвитку серцево-судинних ускладнень в постковідному періоді.

\section{Література:}

1. Голубовська О. А. Постковідний синдром: патогенез та основні напрями реабілітації. Здоров'я України. 2021. Т. 21. № 2 (495). С. 16-18.

2. Коваль С. М., Мисниченко О. В., Пенькова М. Ю. До проблеми взаємозв'язку артеріальної гіпертензії і коронавірусної хвороби (COVID-19): огляд літератури. Артеріальна гіпертензія. Т. 14. № 4. С. 40-45.

3. Пак, А. I. та інші. Ендотеліальна дисфункція при COVID-19 (огляд літератури). 2021. Украӥнський медичний часопис. № 3. С. 7-13.

4. Проскура Т. О. Огляд стійкого постковідного синдрому. Практикуючий лікар. 2021. № 2. С. 53-57.

5. Фещенко Ю. І., Голубовська О.А., Дзюблик О.Я. та інші. Особливості ураження легень при COVID-19. Украӥнський пульмонологічний журнал. 2021, № 1. С. 5-14.

6. Ambrosino P, Calcaterra I, Molino A, Moretta P, Lupoli R, Spedicato GA, et al. Persistent Endothelial Dysfunction in Post-Acute COVID-19 
Syndrome: A Case-Control Study. Biomedicines. 2021. Vol. 9. doi:10.3390/biomedicines9060614.

7. Andrianto, Al-Farabi MJ, Nugraha RA, Marsudi BA, Azmi Y. Biomarkers of endothelial dysfunction and outcomes in coronavirus disease 2019 (COVID-19) patients: A systematic review and meta-analysis. Microvascular Research. 2021. Vol. 138. doi: 10.1016/j.mvr.2021.104224.

8. Fogarty H, Townsend L, Morrin H, Ahmad A et al. Persistent endotheliopathy in the pathogenesis of long COVID syndrome. Journal of Thrombosis and Haemostasis. 2021. Vol. 19. P. 2546-2553. doi:10.1111/jth.15490.

9. Gando S, Wada T. Thromboplasminflammation in COVID-19 Coagulopathy: Three Viewpoints for Diagnostic and Therapeutic Strategies. Frontiers in Immunology. 2021. Vol. 12. doi:10.3389/fimmu.2021.649122

10. Krykhtina M.A., Bielosludtseva K.O., Botvinikova L.A., Matikina N.M. Lung vessels thrombosis in hospitalized patients with communityacquired pneumonia: role of endothelial function, hemostasis, fibrinolysis and inflammation on different phases of treatment. Wiadomości Lekarskie. 2019. Vol. 72 (8). P. 1463-1465.

11. Østergaard L. SARS CoV-2 related microvascular damage and symptoms during and after COVID-19: Consequences of capillary transit-time changes, tissue hypoxia and inflammation. Physiological Reviews. 2021. Vol. 9 (3). https://doi.org/10.14814/phy2.14726.

12. Vieceli Dalla Sega F, Fortini F, Spadaro S, Ronzoni L, Zucchetti O, Manfrini M, et al. Time course of endothelial dysfunction markers and mortality in COVID-19 patients: A pilot study. Clinical and Translational Medicine. 2021. Vol. 11 (3). doi:10.1002/ctm2.283 